\title{
Coronavirus (CoV) proteins (version 2020.4) in the IUPHAR/BPS Guide to Pharmacology Database
}

\author{
Stephen P.H. Alexander ${ }^{1}$, Jonathan K. Ball ${ }^{1}$ and Theocharis Tsoleridis ${ }^{1}$
}

1. University of Nottingham, UK

\begin{abstract}
Coronaviruses are large, often spherical, enveloped, single-stranded positive-sense RNA viruses, ranging in size from 80-220 nm. They can cause diseases ranging from the common cold to severe acute respiratory syndrome (SARS).
\end{abstract}

\section{Contents}

This is a citation summary for Coronavirus (CoV) proteins in the Guide to Pharmacology database (GtoPdb). It exists purely as an adjunct to the database to facilitate the recognition of citations to and from the database by citation analyzers. Readers will almost certainly want to visit the relevant sections of the database which are given here under database links.

GtoPdb is an expert-driven guide to pharmacological targets and the substances that act on them. GtoPdb is a reference work which is most usefully represented as an on-line database. As in any publication this work should be appropriately cited, and the papers it cites should also be recognized. This document provides a citation for the relevant parts of the database, and also provides a reference list for the research cited by those parts.

Please note that the database version for the citations given in GtoPdb are to the most recent preceding version in which the family or its subfamilies and targets were substantially changed. The links below are to the current version. If you need to consult the cited version, rather than the most recent version, please contact the GtoPdb curators.

\section{Database links}

Coronavirus (CoV) proteins

http://www.guidetopharmacology.org/GRAC/FamilyDisplayForward?familyld=1034

Introduction to Coronavirus (CoV) proteins

http://www. guidetopharmacology.org/GRAC/FamilyIntroductionForward?familyld=1034

Targets

CoV Envelope protein

http://www.guidetopharmacology.org/GRAC/ObjectDisplayForward?objectld=3116

CoV 3C-like (main) protease

http://www.guidetopharmacology.org/GRAC/ObjectDisplayForward?objectld=3111

CoV Membrane glycoprotein

http://www.guidetopharmacology.org/GRAC/ObjectDisplayForward?objectld=3117

CoV Non-structural protein 6

http://www.guidetopharmacology.org/GRAC/ObjectDisplayForward?objectld=3118

CoV Non-structural protein $7 \mathrm{~b}$

http://www.guidetopharmacology.org/GRAC/ObjectDisplayForward?objectld=3123

CoV Non-structural protein 8

http://www.guidetopharmacology.org/GRAC/ObjectDisplayForward?objectld=3120

CoV Nucleoprotein

http://www.guidetopharmacology.org/GRAC/ObjectDisplayForward?objectld=3121

CoV Papain-like protease

http://www.guidetopharmacology.org/GRAC/ObjectDisplayForward?objectld=3132

CoV Protein 3a

http://www.guidetopharmacology.org/GRAC/ObjectDisplayForward?objectld=3115

CoV Protein 7a 
http://www.guidetopharmacology.org/GRAC/ObjectDisplayForward?objectld=3119 CoV Protein 9b

http://www.guidetopharmacology.org/GRAC/ObjectDisplayForward?objectld=3122 CoV Replicase polyprotein 1a

http://www.guidetopharmacology.org/GRAC/ObjectDisplayForward?objectld=3124 CoV Replicase polyprotein $1 \mathrm{ab}$

http://www.guidetopharmacology.org/GRAC/ObjectDisplayForward?objectld=3125 CoV RNA-dependent RNA polymerase

http://www.guidetopharmacology.org/GRAC/ObjectDisplayForward?objectld=3139 CoV Spike glycoprotein

http://www.guidetopharmacology.org/GRAC/ObjectDisplayForward?objectld=3114

\section{References}

1. Adedeji AO, Marchand B, Te Velthuis AJ, Snijder EJ, Weiss S, Eoff RL, Singh K and Sarafianos SG. (2012) Mechanism of nucleic acid unwinding by SARS-CoV helicase. PLoS ONE 7: e36521 [PMID:22615777]

2. Ahn DG, Choi JK, Taylor DR and Oh JW. (2012) Biochemical characterization of a recombinant SARS coronavirus nsp12 RNA-dependent RNA polymerase capable of copying viral RNA templates. Arch. Virol. 157: 2095-104 [PMID:22791111]

3. Angelini MM, Akhlaghpour M, Neuman BW and Buchmeier MJ. (2013) Severe acute respiratory syndrome coronavirus nonstructural proteins 3,4 , and 6 induce double-membrane vesicles. $m$ Bio 4: [PMID:23943763]

4. Anson BJ, Chapman ME, Lendy EK, Pshenychnyi S, D'Aquila RT, Satchell KJF and Mesecar AD. (2020) Broad-spectrum inhibition of coronavirus main and papain-like proteases by HCV drugs Nature Research

5. Barretto N, Jukneliene D, Ratia K, Chen Z, Mesecar AD and Baker SC. (2005) The papain-like protease of severe acute respiratory syndrome coronavirus has deubiquitinating activity. J. Virol. 79: 15189-98 [PMID:16306590]

6. Baum A, Fulton BO, Wloga E, Copin R, Pascal KE, Russo V, Giordano S, Lanza K, Negron N and Ni Met al.. (2020) Antibody cocktail to SARS-CoV-2 spike protein prevents rapid mutational escape seen with individual antibodies. Science 369: 1014-1018 [PMID:32540904]

7. Bouvet M, Debarnot C, Imbert I, Selisko B, Snijder EJ, Canard B and Decroly E. (2010) In vitro reconstitution of SARS-coronavirus mRNA cap methylation. PLoS Pathog. 6: e1000863 [PMID:20421945]

8. Bouvet M, Imbert I, Subissi L, Gluais L, Canard B and Decroly E. (2012) RNA 3'-end mismatch excision by the severe acute respiratory syndrome coronavirus nonstructural protein nsp 10/nsp14 exoribonuclease complex. Proc. Natl. Acad. Sci. U.S.A. 109: 9372-7 [PMID:22635272]

9. Báez-Santos YM, Barraza SJ, Wilson MW, Agius MP, Mielech AM, Davis NM, Baker SC, Larsen SD and Mesecar AD. (2014) X-ray structural and biological evaluation of a series of potent and highly selective inhibitors of human coronavirus papain-like proteases. J. Med. Chem. 57: 2393-412 [PMID:24568342]

10. Cao L, Goreshnik I, Coventry B, Case JB, Miller L, Kozodoy L, Chen RE, Carter L, Walls AC and Park YJ et al.. (2020) De novo design of picomolar SARS-CoV-2 miniprotein inhibitors.Science [PMID:32907861]

11. Chen IY, Moriyama M, Chang MF and Ichinohe T. (2019) Severe Acute Respiratory Syndrome Coronavirus Viroporin 3a Activates the NLRP3 Inflammasome. Front Microbiol 10: 50 [PMID:30761102]

12. Chi Y, Yan R, Zhang J, Zhang G, Zhang Y, Hao M, Zhang Z, Fan P, Dong Y and Yang Yet al.. (2020) A neutralizing human antibody binds to the $\mathrm{N}$-terminal domain of the Spike protein of SARS-CoV-2 Science

13. Chinese SARS Molecular Epidemiology Consortium. (2004) Molecular evolution of the SARS coronavirus during the course of the SARS epidemic in China. Science 303: 1666-9 [PMID:14752165]

14. Chuck CP, Chen C, Ke Z, Wan DC, Chow HF and Wong KB. (2013) Design, synthesis and crystallographic analysis of nitrile-based broad-spectrum peptidomimetic inhibitors for coronavirus 3C-like proteases. Eur J Med Chem 59: 1-6 [PMID:23202846]

15. Cornillez-Ty CT, Liao L, Yates 3rd JR, Kuhn P and Buchmeier MJ. (2009) Severe acute respiratory syndrome coronavirus nonstructural protein 2 interacts with a host protein complex involved in mitochondrial biogenesis and intracellular signaling. J. Virol. 83: 10314-8 [PMID:19640993]

16. Cottam EM, Whelband MC and Wileman T. (2014) Coronavirus NSP6 restricts autophagosome expansion. Autophagy 10: 1426-41 [PMID:24991833]

17. Dai W, Zhang B, Su H, Li J, Zhao Y, Xie X, Jin Z, Liu F, Li C and Li łet al.. (2020) Structure-based design of antiviral drug candidates targeting the SARS-CoV-2 main protease. Science [PMID:32321856]

18. Devaraj SG, Wang N, Chen Z, Chen Z, Tseng M, Barretto N, Lin R, Peters CJ, Tseng CT and Baker Set al.. (2007) Regulation of IRF-3-dependent innate immunity by the papain-like protease domain of the severe acute respiratory syndrome coronavirus. J. Biol. Chem. 282: 32208-21 [PMID:17761676]

19. Dong S, Sun J, Mao Z, Wang L, Lu YL and Li J. (2020) A guideline for homology modeling of the proteins from newly discovered betacoronavirus, 2019 novel coronavirus (2019-nCoV). J. Med. Virol. [PMID:32181901]

20. Fan H, Ooi A, Tan YW, Wang S, Fang S, Liu DX and Lescar J. (2005) The nucleocapsid protein of coronavirus infectious bronchitis virus: crystal structure of its $\mathrm{N}$-terminal domain and multimerization properties. Structure 13: 1859-68 [PMID:16338414]

21. Freitas BT, Durie IA, Murray J, Longo JE, Miller HC, Crich D, Hogan RJ, Tripp RA and Pegan SD. (2020) 
Characterization and Noncovalent Inhibition of the Deubiquitinase and delSGylase Activity of SARS-CoV-2 Papain-Like Protease. ACS Infect Dis [PMID:32428392]

22. Fung TS and Liu DX. (2019) Human Coronavirus: Host-Pathogen Interaction.Annu. Rev. Microbiol. 73: 529-557 [PMID:31226023]

23. Ghosh AK, Gong G, Grum-Tokars V, Mulhearn DC, Baker SC, Coughlin M, Prabhakar BS, Sleeman K, Johnson ME and Mesecar AD. (2008) Design, synthesis and antiviral efficacy of a series of potent chloropyridyl ester-derived SARS-CoV 3CLpro inhibitors. Bioorg. Med. Chem. Lett. 18: 5684-8 [PMID:18796354]

24. Gong YN, Tsao KC, Hsiao MJ, Huang CG, Huang PN, Huang PW, Lee KM, Liu YC, Yang SL and Kuo RL et al.. (2020) SARS-CoV-2 genomic surveillance in Taiwan revealed novel ORF8-deletion mutant and clade possibly associated with infections in Middle East. Emerg Microbes Infect 9: 1457-1466 [PMID:32543353]

25. Gordon CJ, Tchesnokov EP, Woolner E, Perry JK, Feng JY, Porter DP and Götte M. (2020) Remdesivir is a direct-acting antiviral that inhibits RNA-dependent RNA polymerase from severe acute respiratory syndrome coronavirus 2 with high potency. J. Biol. Chem. 295: 6785-6797 [PMID:32284326]

26. Gordon DE, Jang GM, Bouhaddou M, Xu J, Obernier K, White KM, O'Meara MJ, Rezelj VV, Guo JZ and Swaney DL et al.. (2020) A SARS-CoV-2 protein interaction map reveals targets for drug repurposing. Nature [PMID:32353859]

27. Hansen J, Baum A, Pascal KE, Russo V, Giordano S, Wloga E, Fulton BO, Yan Y, Koon K and Patel Ket al.. (2020) Studies in humanized mice and convalescent humans yield a SARS-CoV-2 antibody cocktail. Science 369: 1010-1014 [PMID:32540901]

28. Hilgenfeld R. (2014) From SARS to MERS: crystallographic studies on coronaviral proteases enable antiviral drug design. FEBS J. 281: 4085-96 [PMID:25039866]

29. Hoffman R, Kania RS, Brothers MA, Davies JF, Ferre RA, Gajiwala KS, He M, Hogan RJ, Kozminski K and Li LY et al.. (2020) The Discovery of Ketone-Based Covalent Inhibitors of Coronavirus 3CL Proteases for the Potential Therapeutic Treatment of COVID-19 ChemRxiv

30. Hoffmann M, Kleine-Weber H, Schroeder S, Krüger N, Herrler T, Erichsen S, Schiergens TS, Herrler G, Wu NH and Nitsche A et al.. (2020) SARS-CoV-2 Cell Entry Depends on ACE2 and TMPRSS2 and Is Blocked by a Clinically Proven Protease Inhibitor. Cell 181: 271-280.e8 [PMID:32142651]

31. Huo J, Zhao Y, Ren J, Zhou D, Duyvesteyn HME, Ginn HM, Carrique L, Malinauskas T, Ruza RR and Shah PNM et al.. (2020) Neutralisation of SARS-CoV-2 by destruction of the prefusion Spike.Cell Host and Microbe

32. Imbert I, Guillemot JC, Bourhis JM, Bussetta C, Coutard B, Egloff MP, Ferron F, Gorbalenya AE and Canard B. (2006) A second, non-canonical RNA-dependent RNA polymerase in SARS coronavirus. EMBO J. 25: 4933-42 [PMID:17024178]

33. Jin Z, Du X, Xu Y, Deng Y, Liu M, Zhang B, Li X, Zhang L, Peng C and Duan Y. (2020) Structure of Mpro from COVID-19 virus and discovery of its inhibitors bioRxiv

34. Kim SS, Sze L, Liu C and Lam KP. (2019) The stress granule protein G3BP1 binds viral dsRNA and RIG-I to enhance interferon- $\beta$ response. J. Biol. Chem. 294: 6430-6438 [PMID:30804210]

35. Kim SY, Jin W, Sood A, Montgomery DW, Grant OC, Fuster MM, Fu L, Dordick JS, Woods RJ and Zhang F et al.. (2020) Characterization of heparin and severe acute respiratory syndrome-related coronavirus 2 (SARS-CoV-2) spike glycoprotein binding interactions. Antiviral Res. 104873 [PMID:32653452]

36. Kim Y, Jedrzejczak R, Maltseva NI, Wilamowski M, Endres M, Godzik A, Michalska K and Joachimiak A. (2020) Crystal structure of Nsp15 endoribonuclease NendoU from SARS-CoV-2. Protein Sci. [PMID:32304108]

37. Kirchdoerfer RN and Ward AB. (2019) Structure of the SARS-CoV nsp12 polymerase bound to nsp7 and nsp8 co-factors. Nat Commun 10: 2342 [PMID:31138817]

38. Lan J, Ge J, Yu J, Shan S, Zhou H, Fan S, Zhang Q, Shi X, Wang Q and Zhang let al.. (2020) Structure of the SARS-CoV-2 spike receptor-binding domain bound to the ACE2 receptor. Nature [PMID:32225176]

39. Law PTW, Wong CH, Au TCC, Chuck CP, Kong SK, Chan PKS, To KF, Lo AWI, Chan JYW and Suen YK et al.. (2005) The 3a protein of severe acute respiratory syndrome-associated coronavirus induces apoptosis in Vero E6 cells. J. Gen. Virol. 86: 1921-1930 [PMID:15958670]

40. Lindner HA, Lytvyn V, Qi H, Lachance P, Ziomek E and Ménard R. (2007) Selectivity in ISG15 and ubiquitin recognition by the SARS coronavirus papain-like protease. Arch. Biochem. Biophys. 466: 8-14 [PMID:17692280]

41. Liu ZS, Cai H, Xue W, Wang M, Xia T, Li WJ, Xing JQ, Zhao M, Huang YJ and Chen Set al.. (2019) G3BP1 promotes DNA binding and activation of cGAS. Nat. Immunol. 20: 18-28 [PMID:30510222]

42. Lokugamage KG, Narayanan K, Huang C and Makino S. (2012) Severe acute respiratory syndrome coronavirus protein nsp1 is a novel eukaryotic translation inhibitor that represses multiple steps of translation initiation. J. Virol. 86: 13598-608 [PMID:23035226]

43. Lu W, Zheng BJ, Xu K, Schwarz W, Du L, Wong CK, Chen J, Duan S, Deubel V and Sun B. (2006) Severe acute respiratory syndrome-associated coronavirus 3 a protein forms an ion channel and modulates virus release. Proc. Natl. Acad. Sci. U.S.A. 103: 12540-5 [PMID:16894145]

44. Ma C, Sacco MD, Hurst B, Townsend JA, Hu Y, Szeto T, Zhang X, Tarbet B, Marty MT, Y Chen Y and Wang J. (2020) Boceprevir, GC-376, and calpain inhibitors II, XII inhibit SARS-CoV-2 viral replication by targeting the viral main protease bioRxiv

45. Miknis ZJ, Donaldson EF, Umland TC, Rimmer RA, Baric RS and Schultz LW. (2009) Severe acute respiratory syndrome coronavirus nsp9 dimerization is essential for efficient viral growth. J. Virol. 83: 3007- 
18 [PMID:19153232]

46. Minakshi R, Padhan K, Rani M, Khan N, Ahmad F and Jameel S. (2009) The SARS Coronavirus 3a protein causes endoplasmic reticulum stress and induces ligand-independent downregulation of the type 1 interferon receptor. PLoS ONE 4: e8342 [PMID:20020050]

47. Muth D, Corman VM, Roth H, Binger T, Dijkman R, Gottula LT, Gloza-Rausch F, Balboni A, Battilani M and Rihtarič D et al.. (2018) Attenuation of replication by a 29 nucleotide deletion in SARS-coronavirus acquired during the early stages of human-to-human transmission. Sci Rep 8: 15177 [PMID:30310104]

48. Nakagawa K, Narayanan K, Wada M and Makino S. (2018) Inhibition of Stress Granule Formation by Middle East Respiratory Syndrome Coronavirus 4a Accessory Protein Facilitates Viral Translation, Leading to Efficient Virus Replication. J. Virol. 92: [PMID:30068649]

49. Nelson CA, Pekosz A, Lee CA, Diamond MS and Fremont DH. (2005) Structure and intracellular targeting of the SARS-coronavirus Orf7a accessory protein. Structure 13: 75-85 [PMID:15642263]

50. Nieto-Torres JL, Verdiá-Báguena C, Jimenez-Guardeño JM, Regla-Nava JA, Castaño-Rodriguez C, Fernandez-Delgado R, Torres J, Aguilella VM and Enjuanes L. (2015) Severe acute respiratory syndrome coronavirus E protein transports calcium ions and activates the NLRP3 inflammasome. Virology 485: 3309 [PMID:26331680]

51. Peng Q, Peng R, Yuan B, Zhao J, Wang M, Wang X, Sun Y, Fan Z, Qi J and Gao Gret al.. (2020) Structural and biochemical characterization of nsp12-nsp7-nsp8 core polymerase complex from SARSCoV-2 Cell Reports

52. Pervushin K, Tan E, Parthasarathy K, Lin X, Jiang FL, Yu D, Vararattanavech A, Soong TW, Liu DX and Torres J. (2009) Structure and inhibition of the SARS coronavirus envelope protein ion channel. PLoS Pathog. 5: e1000511 [PMID:19593379]

53. Petersen E, Koopmans M, Go U, Hamer DH, Petrosillo N, Castelli F, Storgaard M, Al Khalili S and Simonsen L. (2020) Comparing SARS-CoV-2 with SARS-CoV and influenza pandemics. Lancet Infect Dis [PMID:32628905]

54. Pfefferle S, Krähling V, Ditt V, Grywna K, Mühlberger E and Drosten C. (2009) Reverse genetic characterization of the natural genomic deletion in SARS-Coronavirus strain Frankfurt-1 open reading frame $7 \mathrm{~b}$ reveals an attenuating function of the $7 \mathrm{~b}$ protein in-vitro and in-vivo. Virol. J. 6: 131 [PMID:19698190]

55. Pillaiyar T, Manickam M, Namasivayam V, Hayashi Y and Jung SH. (2016) An Overview of Severe Acute Respiratory Syndrome-Coronavirus (SARS-CoV) 3CL Protease Inhibitors: Peptidomimetics and Small Molecule Chemotherapy. J. Med. Chem. 59: 6595-628 [PMID:26878082]

56. PostEra Al. MPro Activity Data

57. Pruijssers AJ and Denison MR. (2019) Nucleoside analogues for the treatment of coronavirus infections. Curr Opin Viro/ 35: 57-62 [PMID:31125806]

58. Rathnayake AD, Zheng J, Kim Y, Perera KD, Mackin S, Meyerholz DK, Kashipathy MM, Battaile KP, Lovell S and Perlman S et al.. (2020) 3C-like protease inhibitors block coronavirus replication in vitro and improve survival in MERS-CoV-infected mice. Sci Transl Med 12: [PMID:32747425]

59. Ratia K, Pegan S, Takayama J, Sleeman K, Coughlin M, Baliji S, Chaudhuri R, Fu W, Prabhakar BS and Johnson ME et al.. (2008) A noncovalent class of papain-like protease/deubiquitinase inhibitors blocks SARS virus replication. Proc. Natl. Acad. Sci. U.S.A. 105: 16119-24 [PMID:18852458]

60. Riva L, Yuan S, Yin X, Martin-Sancho L, Matsunaga N, Pache L, Burgstaller-Muehlbacher S, De Jesus PD, Teriete P and Hull MV et al.. (2020) Discovery of SARS-CoV-2 antiviral drugs through large-scale compound repurposing Nature

61. Ruch TR and Machamer CE. (2012) The coronavirus E protein: assembly and beyond. Viruses 4: 363-82 [PMID:22590676]

62. Saikatendu KS, Joseph JS, Subramanian V, Clayton T, Griffith M, Moy K, Velasquez J, Neuman BW, Buchmeier MJ and Stevens RC et al.. (2005) Structural basis of severe acute respiratory syndrome coronavirus ADP-ribose-1"-phosphate dephosphorylation by a conserved domain of nsP3. Structure 13: 1665-75 [PMID:16271890]

63. Shi CS, Qi HY, Boularan C, Huang NN, Abu-Asab M, Shelhamer JH and Kehrl JH. (2014) SARScoronavirus open reading frame-9b suppresses innate immunity by targeting mitochondria and the MAVS/TRAF3/TRAF6 signalosome. J. Immunol. 193: 3080-9 [PMID:25135833]

64. Su YCF, Anderson DE, Young BE, Linster M, Zhu F, Jayakumar J, Zhuang Y, Kalimuddin S, Low JGH and Tan CW et al.. (2020) Discovery and Genomic Characterization of a 382-Nucleotide Deletion in ORF7b and ORF8 during the Early Evolution of SARS-CoV-2. mBio 11: [PMID:32694143]

65. Surya $\mathrm{W}, \mathrm{Li} \mathrm{Y}$, Verdià-Bàguena $\mathrm{C}$, Aguilella VM and Torres J. (2015) MERS coronavirus envelope protein has a single transmembrane domain that forms pentameric ion channels. Virus Res. 201: 61-6 [PMID:25733052]

66. Tan YJ, Fielding BC, Goh PY, Shen S, Tan TH, Lim SG and Hong W. (2004) Overexpression of 7a, a protein specifically encoded by the severe acute respiratory syndrome coronavirus, induces apoptosis via a caspase-dependent pathway. J. Virol. 78: 14043-7 [PMID:15564512]

67. Tanner JA, Watt RM, Chai YB, Lu LY, Lin MC, Peiris JS, Poon LL, Kung HF and Huang JD. (2003) The severe acute respiratory syndrome (SARS) coronavirus NTPase/helicase belongs to a distinct class of $5^{\prime}$ to 3' viral helicases. J. Biol. Chem. 278: 39578-82 [PMID:12917423]

68. te Velthuis AJ, van den Worm SH and Snijder EJ. (2012) The SARS-coronavirus nsp7+nsp8 complex is a unique multimeric RNA polymerase capable of both de novo initiation and primer extension. Nucleic Acids 
Res. 40: 1737-47 [PMID:22039154]

69. ter Meulen J, van den Brink EN, Poon LL, Marissen WE, Leung CS, Cox F, Cheung CY, Bakker AQ, Bogaards JA and van Deventer E et al.. (2006) Human monoclonal antibody combination against SARS coronavirus: synergy and coverage of escape mutants. PLoS Med. 3: e237 [PMID:16796401]

70. Thoms M, Buschauer R, Ameismeier M, Koepke L, Denk T, Hirschenberger M, Kratzat H, Hayn M, Mackens-Kiani T and Cheng J et al.. (2020) Structural basis for translational shutdown and immune evasion by the Nsp1 protein of SARS-CoV-2. Science [PMID:32680882]

71. Tian X, Li C, Huang A, Xia S, Lu S, Shi Z, Lu L, Jiang S, Yang Z and Wu Yet al.. (2020) Potent binding of 2019 novel coronavirus spike protein by a SARS coronavirus-specific human monoclonal antibody. Emerg Microbes Infect 9: 382-385 [PMID:32065055]

72. Vasilenko N, Moshynskyy I and Zakhartchouk A. (2010) SARS coronavirus protein 7a interacts with human Ap4A-hydrolase. Virol. J. 7: 31 [PMID:20144233]

73. Walls AC, Park YJ, Tortorici MA, Wall A, McGuire AT and Veesler D. (2020) Structure, Function, and Antigenicity of the SARS-CoV-2 Spike Glycoprotein. Cell 181: 281-292.e6 [PMID:32155444]

74. Wang Q, Zhang Y, Wu L, Niu S, Song C, Zhang Z, Lu G, Qiao C, Hu Y and Yuen KYet al.. (2020) Structural and Functional Basis of SARS-CoV-2 Entry by Using Human ACE2. Cell 181: 894-904.e9 [PMID:32275855]

75. Wang Y, Anirudhan V, Du R, Cui Q and Rong L. (2020) RNA-dependent RNA polymerase of SARS-CoV-2 as a therapeutic target. J. Med. Virol. [PMID:32633831]

76. Wilson L, McKinlay C, Gage P and Ewart G. (2004) SARS coronavirus E protein forms cation-selective ion channels. Virology 330: 322-31 [PMID:15527857]

77. Wiser C, Kim B and Ascano M. (2019) G3BP1 enhances cytoplasmic DNA pattern recognition. Nat. Immunol. 20: 5-7 [PMID:30538338]

78. Węglarz-Tomczak E, Tomczak JM, Talma M and Brul S. (2020) Ebselen as a highly active inhibitor of PLProCoV2 bioRxiv

79. Xu K, Zheng BJ, Zeng R, Lu W, Lin YP, Xue L, Li L, Yang LL, Xu C and Dai et al.. (2009) Severe acute respiratory syndrome coronavirus accessory protein $9 \mathrm{~b}$ is a virion-associated protein. Virology 388: 279-85 [PMID:19394665]

80. Yan R, Zhang Y, Li Y, Xia L, Guo Y and Zhou Q. (2020) Structural basis for the recognition of SARS-CoV2 by full-length human ACE2. Science 367: 1444-1448 [PMID:32132184]

81. Yang $H$, Xie W, Xue X, Yang K, Ma J, Liang W, Zhao Q, Zhou Z, Pei D and Ziebuhr \&t al.. (2005) Design of wide-spectrum inhibitors targeting coronavirus main proteases. PLoS Biol. 3: e324 [PMID:16128623]

82. Yang KS, Ma XR, Ma Y, Alugubelli YR, Scott DA, Vatansever EC, Drelich AK, Sankaran B, Geng ZZ and Blankenship LR et al.. (2020) A Speedy Route to Multiple Highly Potent SARS-CoV-2 Main Protease Inhibitors. bioRxiv [PMID:32766582]

83. Yang S, Chen SJ, Hsu MF, Wu JD, Tseng CT, Liu YF, Chen HC, Kuo CW, Wu CS and Chang LWet al.. (2006) Synthesis, crystal structure, structure-activity relationships, and antiviral activity of a potent SARS coronavirus 3CL protease inhibitor. J. Med. Chem. 49: 4971-80 [PMID:16884309]

84. Yang W, Ru Y, Ren J, Bai J, Wei J, Fu S, Liu X, Li D and Zheng H. (2019) G3BP1 inhibits RNA virus replication by positively regulating RIG-I-mediated cellular antiviral response. Cell Death Dis 10: 946 [PMID:31827077]

85. Yoshimoto FK. (2020) The Proteins of Severe Acute Respiratory Syndrome Coronavirus-2 (SARS CoV-2 or n-COV19), the Cause of COVID-19 The Protein Journal volume 39: 198-216

86. Young BE, Fong S-W, Chan Y-H, Mak T-M, Ang LW and Anderson DE. (2020) Effects of a major deletion in the SARS-CoV-2 genome on the severity of infection and the inflammatory response: an observational cohort study The Lancet

87. Yuan M, Wu NC, Zhu X, Lee CD, So RTY, Lv H, Mok CKP and Wilson IA. (2020) A highly conserved cryptic epitope in the receptor binding domains of SARS-CoV-2 and SARS-CoV. Science 368: 630-633 [PMID:32245784]

88. Zaher NH, Mostafa MI and Altaher AY. (2020) Design, synthesis and molecular docking of novel triazole derivatives as potential CoV helicase inhibitors. Acta Pharm 70: 145-159 [PMID:31955138]

89. Zhang L, Li L, Yan L, Ming Z, Jia Z, Lou Z and Rao Z. (2018) Structural and Biochemical Characterization of Endoribonuclease Nsp15 Encoded by Middle East Respiratory Syndrome Coronavirus. J. Virol. 92: [PMID:30135128]

90. Zhang L, Lin D, Kusov Y, Nian Y, Ma Q, Wang J, von Brunn A, Leyssen P, Lanko K and Neyts et al.. (2020) a-Ketoamides as Broad-Spectrum Inhibitors of Coronavirus and Enterovirus Replication: StructureBased Design, Synthesis, and Activity Assessment. J. Med. Chem. 63: 4562-4578 [PMID:32045235]

91. Zhang L, Lin D, Sun X, Curth U, Drosten C, Sauerhering L, Backer S, Rox K and Hilgenfeld R. (2020) Crystal structure of SARS-CoV-2 main protease provides a basis for design of improved a-ketoamide inhibitors Science

92. Zhang L, Lin D, Sun X, Curth U, Drosten C, Sauerhering L, Becker S, Rox K and Hilgenfeld R. (2020) Crystal structure of SARS-CoV-2 main protease provides a basis for design of improved a-ketoamide inhibitors. Science 368: 409-412 [PMID:32198291]

93. Zhang R, Wang K, Lv W, Yu W, Xie S, Xu K, Schwarz W, Xiong S and Sun B. (2014) The ORF4a protein of human coronavirus $229 \mathrm{E}$ functions as a viroporin that regulates viral production. Biochim. Biophys. Acta 1838: 1088-95 [PMID:23906728]

94. Zhu W, Chen CZ, Gorshkov K, Xu M, Lo DC and Zheng W. (2020) RNA-Dependent RNA Polymerase as a Target for COVID-19 Drug Discovery. SLAS Discov 2472555220942123 [PMID:32660307] 
95. Zhu W, Xu M, Chen CZ, Guo H, Shen M, Hu X, Shinn P, Klumpp-Thomas C, Michael SG and Zheng W. (2020) Identification of SARS-CoV-2 3CL Protease Inhibitors by a Quantitative High-throughput Screening. ACS Pharmacol. Transl. Sci. 